Supporting Information

\title{
Recyclable Palladium-loaded Hyperbranched Polytriazoles as Efficient Polymer Catalysts for Heck Reaction
}

\author{
Weiping Gan, Hui Xu, Xiuyu Jin, Xiaosong Cao, Haifeng Gao* \\ Department of Chemistry and Biochemistry, University of Notre Dame, Notre Dame, Indiana \\ 46556, United States \\ * Corresponding author. Email: hgao@nd.edu
}

Materials. Sodium azide (EMD Millipore, 99\%), 1-hexyne (Acros Organics, 98\%), ascorbic acid (Alfa Aesar, $\geq 99 \%$ ), copper(II) sulfate pentahydrate $\left(\mathrm{CuSO}_{4} \cdot 5 \mathrm{H}_{2} \mathrm{O}, \mathrm{BDH}, \mathrm{ACS}\right.$ grade), $N, N, N^{\prime}, N^{\prime}, N^{\prime}$-pentamethyldiethylenetriamine (PMDETA, Sigma-Aldrich, 99\%), iodobenzene (TCI America, $\geq 99 \%$ ), palladium(II) acetate $\left(\mathrm{Pd}(\mathrm{OAc})_{2}\right.$, TCI America, $\geq 98 \%$ ), styrene (EMD Millipore, $\geq 99 \%$ ), potassium phosphate tribasic, anhydrous $\left(\mathrm{K}_{3} \mathrm{PO}_{4}\right.$, Acros Organics, 97\%), copper(I) iodide (CuI, Sigma-Aldrich, 98\%), 2-ethynylpyridine (Ark Pharm, 98\%), 1-bromobutane (TCI America, > 98\%), phenylacetylene (BeanTown Chemical, 98\%), pentasodium diethylenetriaminepentaacetate (Na5DTPA, TCI America, 1.0 mol/L, 40\%) 1methyl-2-pyrrolidinone (Alfa Aesar, $\geq 99 \%$ ), dimethylformamide (DMF, Sigma-Aldrich, $\geq$ 99.8\%), diethyl ether (EMD Millipore, $\geq 99 \%$ ), dichloromethane (DCM, Sigma-Aldrich, > 99.5\%), deuterated chloroform ( $\mathrm{CDCl}_{3}$, Alfa Aesar, 99.8\%), dimethylformamide- $d_{7}$ (DMF- $d_{7}$, Alfa Aesar, 100\%) were used as received. 3-Azido-2-(azidomethyl)-2- 
((isobutyryloxy)methyl)propyl pent-4-ynoate $\left(\mathrm{AB}_{2}\right.$ monomer $),{ }^{1} \operatorname{tris}((1-(3-a z i d o p r o p y l)-1 \mathrm{H}-$ 1,2,3-triazol-4-yl)methyl)amine ( $\mathrm{B}_{3}$ core $)^{2}$ and alkyne-terminated polyethylene glycol with $\mathrm{M}_{\mathrm{n}}$ $\sim 2000\left(\text { ay- } \mathrm{PEG}_{2 \mathrm{k}}\right)^{3}$ were synthesized according to published procedures. Regarding the explosive nature, all azide compounds were synthesized, purified and stored according to the standard safety rules with caution. ${ }^{4}$

Characterization. The DMF size exclusion chromatography (SEC) was equipped with a Waters 515 HPLC pump, Polymer Standards Services (PSS) columns (GRAM, 10 $410^{3}$, and $10^{2} \AA$ ) at $55^{\circ} \mathrm{C}$ with DMF flow rate $=1.00 \mathrm{~mL} \mathrm{~min}^{-1}$, a Wyatt differential refractive index (RI) detector (Wyatt Technology, Optilab T-rEX) using PSS WinGPC 7.5 software. The apparent molecular weights were calculated based on linear poly(methyl methacrylate) (PMMA) standards. ${ }^{1} \mathrm{H}$ and ${ }^{13} \mathrm{C}$ nuclear magnetic resonance (NMR) spectroscopy was acquired on a Bruker $500 \mathrm{MHz}$ spectrometer at $25^{\circ} \mathrm{C}$ using $\mathrm{CDCl}_{3}$ and DMF- $d 7$ as solvents. The analyses of metal elements in samples were conducted by Inductively Coupled Plasma-Optical Emission Spectrometry (ICP-OES, Optima 8000, PerkinElmer, U.S.A.) with the ESI SC2 autosampler and Prep3 inlet system. For ICP-OES analysis, the dried sample of about $2 \mathrm{mg}$ was burned under $360{ }^{\circ} \mathrm{C}$ for $3 \mathrm{~h}$ before digested for about $6 \mathrm{~h}$ in $2 \mathrm{ml}$ mixed acids of concentrated $\mathrm{HNO}_{3}$ and $\mathrm{HCl}(3: 1, \mathrm{v} / \mathrm{v})$. The digested sample was then diluted to $10 \mathrm{~mL}$ with distilled water. In ICPOES analysis, operating conditions included nebulizer flow of $1.5 \mathrm{~L} / \mathrm{min}$, sample introduction flow of $0.37 \mathrm{~mL} / \mathrm{min}$, flush time of $10 \mathrm{~s}$, delay time of $40 \mathrm{~s}$, and wash time of $40 \mathrm{~s}$. For characterization of each metal residue, five solutions of metal salt in known concentrations were prepared and analyzed to establish calibration curves for quantitative determination. Each sample was tested in triplicate for quality assurance. 
Synthesis of $\mathrm{HBP}_{30}-\mathrm{N}_{3}$ by $\mathrm{CuAAC}$ polymerization of $\mathrm{AB}_{2}$ with $\mathrm{B}_{3}$ core. Monomer

$\mathrm{AB}_{2}(400.0 \mathrm{mg}, 1.19 \mathrm{mmol}), \mathrm{B}_{3}$ core $(20.2 \mathrm{mg}, 0.04 \mathrm{mmol})$, and $\mathrm{CuSO}_{4} \cdot 5 \mathrm{H}_{2} \mathrm{O}(49.5 \mathrm{mg}, 0.20$ mmol) were dissolved in $2.4 \mathrm{~mL}$ of DMF in a Schlenk flask. The flask was degassed by three freeze-pump-thaw cycles. At the last cycle, the flask was opened when everything was frozen to quickly add ascorbic acid $(69.8 \mathrm{mg}, 0.40 \mathrm{mmol})$ into the flask before re-capping. The flask was vacuumed and backfilled with $\mathrm{N}_{2}$ for 3 cycles before immersed in a thermostatic oil bath at $45{ }^{\circ} \mathrm{C}$ to thaw the mixture solution and initiate the polymerization. The polymerization was stopped at 6 hours and the reaction mixture was diluted with $10 \mathrm{~mL}$ DCM. Copper catalyst was removed by adding three equivalents of PMDETA followed by passing through a neutral alumina column. The hyperbranched polymer (HBP) was then purified by dissolving in small amount of DCM and precipitating into large amount of diethyl ether for three times. The final product was dried under vacuum as sticky solid.
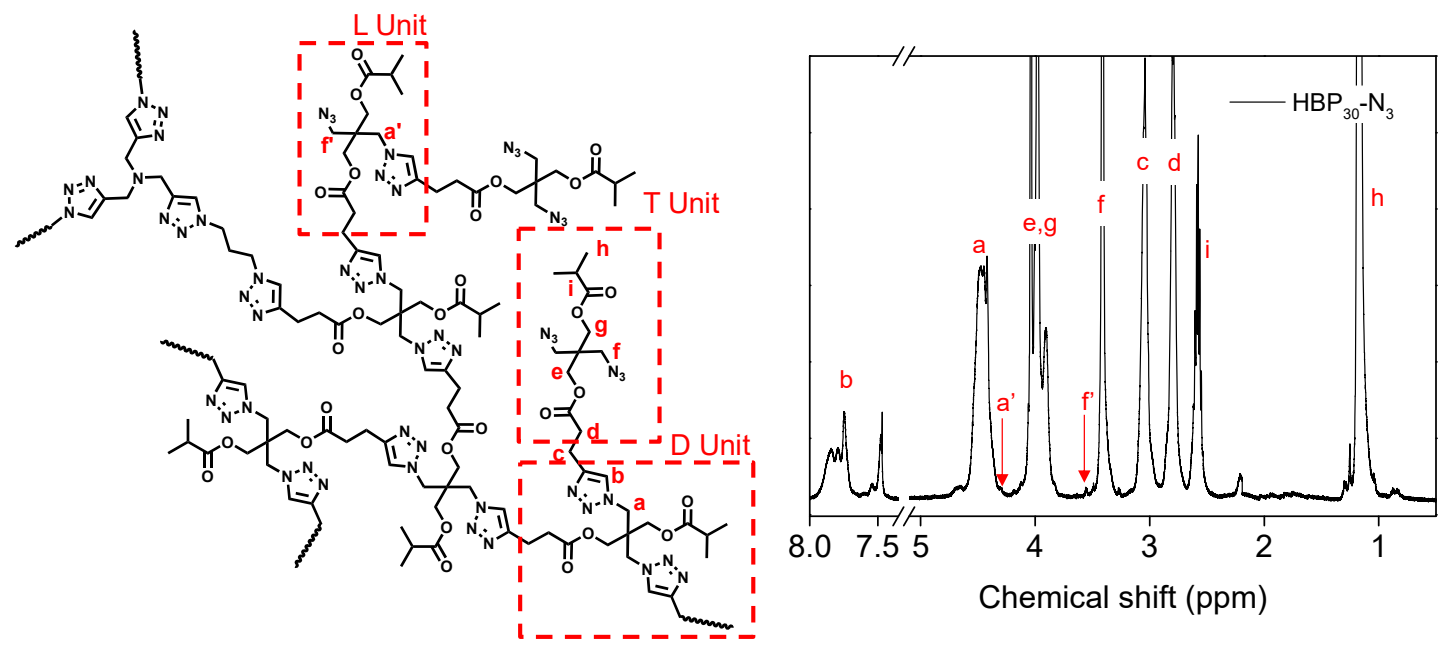

Figure S1. Structure and ${ }^{1} \mathrm{H}$ NMR spectrum of $\mathrm{HBP}_{30}-\mathrm{N}_{3}$. 
Synthesis of $\mathrm{HBP}_{300}-\mathrm{N}_{3}$ by $\mathrm{CuAAC}$ polymerization of $\mathrm{AB}_{2}$ with $\mathrm{B}_{3}$ core. Monomer $\mathrm{AB}_{2}(500.0 \mathrm{mg}, 1.49 \mathrm{mmol}), \mathrm{B}_{3}$ core $(2.5 \mathrm{mg}, 5.0 \mu \mathrm{mol})$, and $\mathrm{CuSO}_{4} \cdot 5 \mathrm{H}_{2} \mathrm{O}(6.2 \mathrm{mg}, 24.8 \mu \mathrm{mol})$ were dissolved in $3.0 \mathrm{~mL}$ of DMF in a Schlenk flask. The flask was degassed by three freezepump-thaw cycles. At the last cycle, the flask was opened when everything was frozen to quickly add ascorbic acid $(8.7 \mathrm{mg}, 49.6 \mu \mathrm{mol})$ into the flask before re-capping. The flask was vacuumed and backfilled with $\mathrm{N}_{2}$ for 3 cycles before immersed in a thermostatic oil bath at $45{ }^{\circ} \mathrm{C}$ to thaw the mixture solution and initiate the polymerization. The polymerization was stopped at 3 hours and the reaction mixture was diluted with $10 \mathrm{~mL}$ DCM. Copper catalyst was removed by adding three equivalents of PMDETA followed by passing through a neutral alumina column. The HBP was then purified by dissolving in small amount of DCM and precipitating into large amount of diethyl ether for three times. The final product was dried under vacuum as sticky solid.

Synthesis of $\mathrm{HBP}_{30}-\mathrm{Py}$ by $\mathbf{C u A A C}$ reaction. A mixture of $50 \mathrm{mg} \mathrm{HBP}_{30}-\mathrm{N}_{3}$ polymer, $23 \mathrm{mg}$ 2-ethynylpyridine, $1.8 \mathrm{mg} \mathrm{CuSO}_{4} \cdot 5 \mathrm{H}_{2} \mathrm{O}$ and $0.4 \mathrm{~mL}$ DMF was charged in a $10 \mathrm{~mL}$ Schlenk flask. The flask was degassed by three freeze-pump-thaw cycles. At the last cycle, the flask was opened when everything was frozen to quickly add ascorbic acid (2.6 mg) into the flask before re-capping. The flask was vacuumed and backfilled with $\mathrm{N}_{2}$ for 3 cycles before immersed in a thermostatic oil bath at $45{ }^{\circ} \mathrm{C}$ to thaw the mixture solution. The reaction was stopped at 12 hours and diluted with $2 \mathrm{~mL} \mathrm{DCM}$, and $\mathrm{Cu}$ catalyst was removed by adding two equivalents of PMDETA followed by passing a neutral alumina column, the pyridyl-capped polymer $\left(\mathrm{HBP}_{30}-\mathrm{Py}\right)$ was then purified by precipitating into large amount of diethyl ether three times. 


\section{Synthesis of $\mathrm{HBP}_{300}-\mathrm{Py}, \mathrm{HBP}_{300}-\mathrm{Ph}$ and $\mathrm{HBP}_{300}-\mathrm{PEG}_{2 \mathrm{k}}$ by $\mathrm{CuAAC}$ capping}

reaction. The procedures for the synthesis of $\mathrm{HBP}_{300-P y}$ were similar to those described above except replacing $\mathrm{HBP}_{30}-\mathrm{N}_{3}(50 \mathrm{mg})$ with $\mathrm{HBP}_{300}-\mathrm{N}_{3}(50 \mathrm{mg})$. The procedures for the synthesis of $\mathrm{HBP}_{300}-\mathrm{Ph}$ and $\mathrm{HBP}_{300}-\mathrm{PEG}_{2 \mathrm{k}}$ were similar to those described above except replacing $\mathrm{HBP}_{30}-\mathrm{N}_{3}(50 \mathrm{mg})$ with $\mathrm{HBP}_{300}-\mathrm{N}_{3}(50 \mathrm{mg})$ and replacing 2-ethynylpyridine $(23 \mathrm{mg})$ with phenylacetylene $(23 \mathrm{mg})$ and ay-PEG $2 \mathrm{k}(446 \mathrm{mg})$.

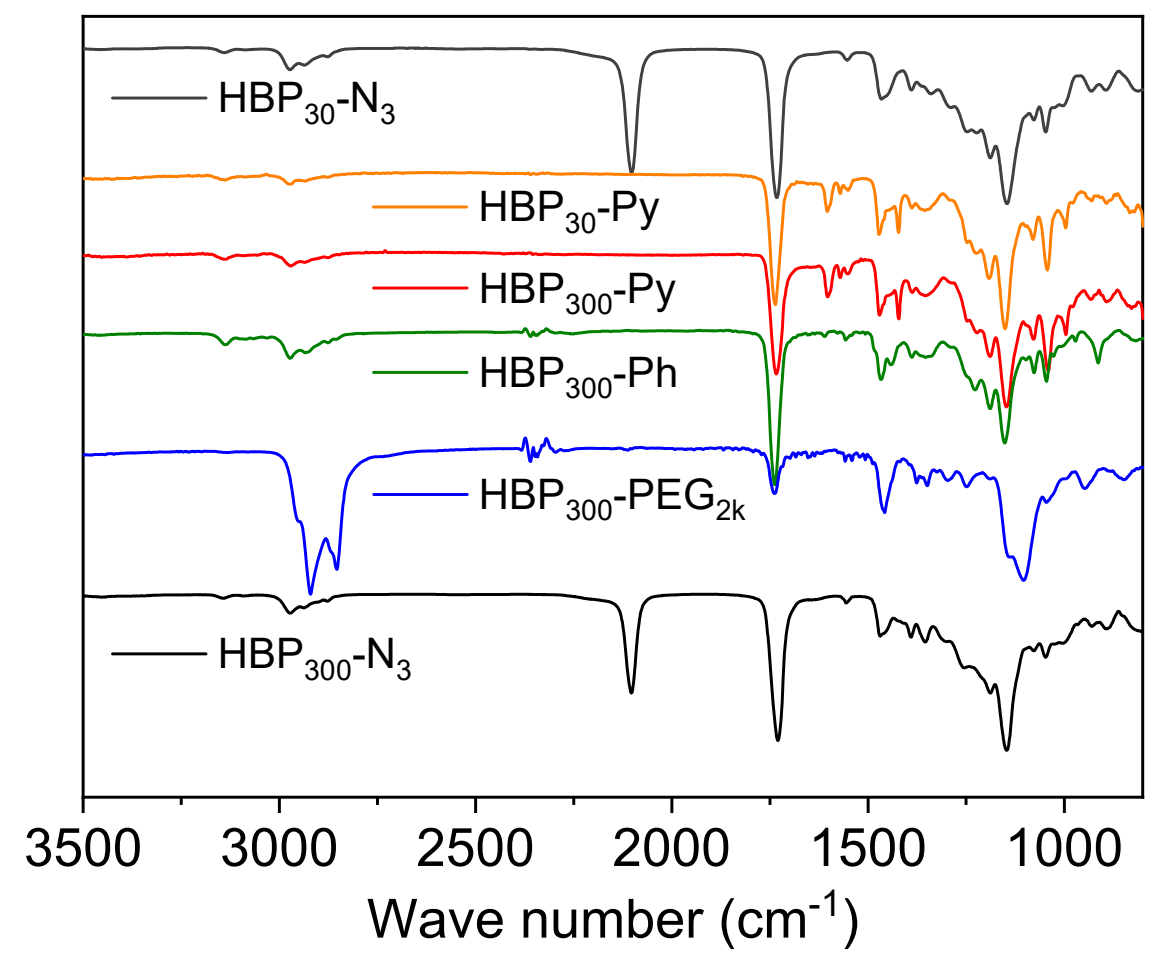

Figure S2. FT-IR spectra of $\mathrm{HBP}_{30}-\mathrm{N}_{3}, \mathrm{HBP}_{30}-\mathrm{Py}, \mathrm{HBP}_{300}-\mathrm{N}_{3}, \mathrm{HBP}_{300}-\mathrm{Py}, \mathrm{HBP}_{300}-\mathrm{Ph}$ and $\mathrm{HBP}_{300}-\mathrm{PEG}_{2 \mathrm{k}}$. 


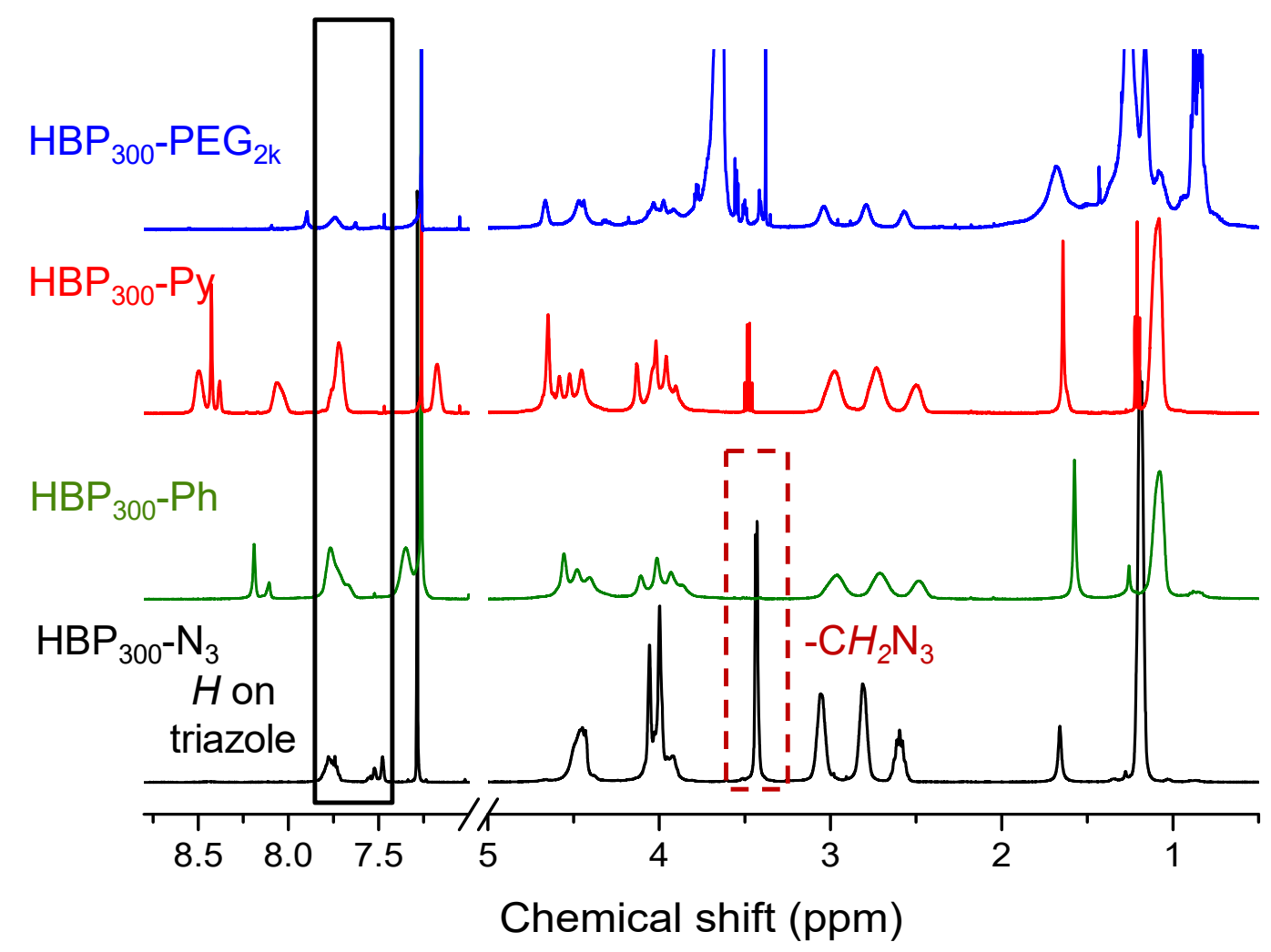

Figure S3. ${ }^{1} \mathrm{H}$ NMR spectra of $\mathrm{HBP}_{300}-\mathrm{N}_{3}, \mathrm{HBP}_{300}-\mathrm{Py}, \mathrm{HBP}_{300}-\mathrm{Ph}$ and $\mathrm{HBP}_{300}-\mathrm{PEG}_{2 \mathrm{k}}$.

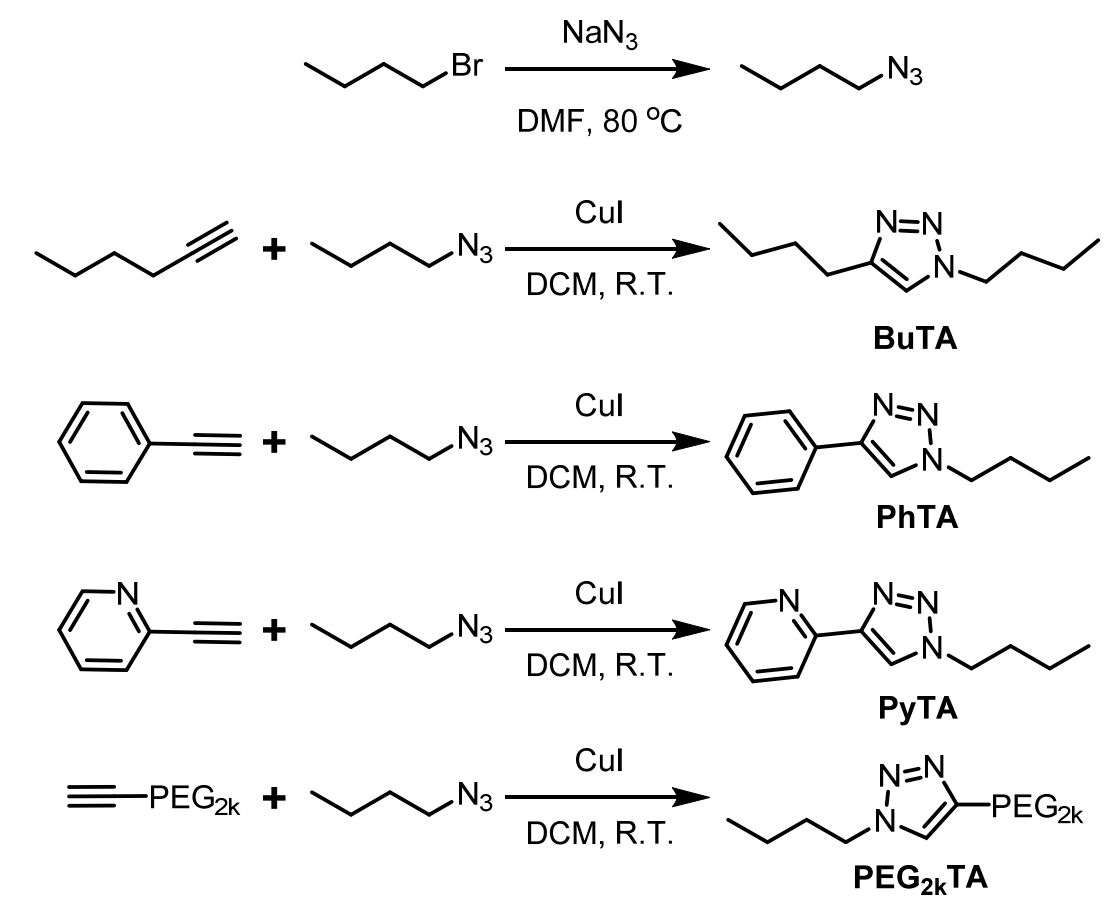

Scheme S1. Synthetic procedures of model ligands BuTA, PhTA, PyTA and PEG $2 \mathrm{kTA}$. 
Synthesis of 1-azidobutane. To a $250 \mathrm{~mL}$ round bottomed flash were added sequentially with 1-bromobutane (16.44 g, $120.0 \mathrm{mmol})$, sodium azide (9.36 g, $144.0 \mathrm{mmol})$ and $100 \mathrm{~mL}$ DMF. The reaction mixture was stirred at $80^{\circ} \mathrm{C}$ overnight before $100 \mathrm{~mL}$ distilled water was added and the reaction mixture was extracted by diethyl ether $(200 \mathrm{~mL} \times 4)$ and dried over $\mathrm{MgSO}_{4}$. The solvent was evaporated to give a colorless oil of 1-azidobutane $(9.36 \mathrm{~g}, 83 \%$ purity, $65 \%$ yield).

Synthesis of model ligand BuTA. To a $10 \mathrm{~mL}$ Schlenk flask were added sequentially with 1-azidobutane (557.3 mg, $4.64 \mathrm{mmol}), 1$-hexyne (389.3 mg, $4.64 \mathrm{mmol}), \mathrm{CuI}$ (44.1 mg, $0.232 \mathrm{mmol}$ ) and $3 \mathrm{~mL} \mathrm{DCM}$. The reaction mixture was allowed to be stirred at room temperature overnight before $3 \mathrm{~mL}$ DCM was added and the reaction mixture was washed with $5 \%$ NasDTPA aqueous solution $(5 \mathrm{~mL} \times 2)$ and brine $(5 \mathrm{~mL} \times 2)$ and dried over $\mathrm{MgSO}_{4}$. The solvent was evaporated, and the remaining residual was purified by flash silica gel chromatography (hexanes/ethyl acetate, $3: 1 \mathrm{v} / \mathrm{v}$ ) to give $0.804 \mathrm{~g}$ colorless oil of the targeted BuTA (85\% yield). ${ }^{1} \mathrm{H}$ NMR (500 MHz, $\left.\mathrm{CDCl}_{3}, 25^{\circ} \mathrm{C}\right) \delta(\mathrm{ppm}): 0.93\left(\mathrm{~m}, 6 \mathrm{H}, \mathrm{CH}_{3}\right) 1.36(\mathrm{~m}$, $\left.4 \mathrm{H}, \mathrm{CH}_{3} \mathrm{CH}_{2}\right), 1.65\left(\mathrm{~m}, 2 \mathrm{H}, \mathrm{CH}_{2} \mathrm{CH}_{2} \mathrm{CH}_{2} \mathrm{C}\right), 1.86\left(\mathrm{~m}, 2 \mathrm{H}, \mathrm{CH}_{2} \mathrm{CH}_{2} \mathrm{CH}_{2} \mathrm{~N}\right), 2.71$ (t, 2H, $\left.\mathrm{CH}_{2} \mathrm{CH}_{2} \mathrm{C}\right), 4.30\left(\mathrm{t}, 2 \mathrm{H}, \mathrm{CH}_{2} \mathrm{CH}_{2} \mathrm{~N}\right), 7.25(\mathrm{~s}, 1 \mathrm{H}, \mathrm{NCHC}) .{ }^{13} \mathrm{C} \mathrm{NMR}\left(500 \mathrm{MHz}, \mathrm{CDCl}_{3}, 25{ }^{\circ} \mathrm{C}\right)$ $\delta$ (ppm): 148.6, 120.7, 50.1, 32.5, 31.9, 25.6, 22.7, 20.1, 14.2 and 13.8. (Figure S4)

Synthesis of model ligand PhTA and PyTA. The procedures for the syntheses of PyTA and PhTA were similar to those described above except replacing 1-hexyne with 2ethynylpyridine (488.2 mg, $4.64 \mathrm{mmol})$ and phenylacetylene (483.6 mg, $4.64 \mathrm{mmol})$. PyTA: ${ }^{1} \mathrm{H}$ NMR (500 MHz, $\left.\mathrm{CDCl}_{3}, 25{ }^{\circ} \mathrm{C}\right) \delta(\mathrm{ppm}): 0.94(\mathrm{t}, 3 \mathrm{H}, \mathrm{CH}) 1.41\left(\mathrm{~m}, 2 \mathrm{H}, \mathrm{CH}_{3} \mathrm{CH}_{2}\right), 1.93$ 
(m, 2H, $\left.\mathrm{CH}_{2} \mathrm{CH}_{2} \mathrm{~N}\right), 4.42\left(\mathrm{t}, 2 \mathrm{H}, \mathrm{CH}_{2} \mathrm{CH}_{2} \mathrm{~N}\right), 7.23(\mathrm{~m}, 1 \mathrm{H}, \mathrm{ArH}), 7.78(\mathrm{~m}, 1 \mathrm{H}, \mathrm{ArH}), 8.14-8.22$ (m, 2H, NCHC and $\mathrm{ArH}$ ) and $8.59(\mathrm{~m}, 1 \mathrm{H}, \mathrm{Ar} H) .{ }^{13} \mathrm{C} \mathrm{NMR}\left(500 \mathrm{MHz}, \mathrm{CDCl}_{3}, 25^{\circ} \mathrm{C}\right) \delta(\mathrm{ppm})$ : 150.5, 149.4, 148.3, 136.9, 122.9, 121.8, 120.2, 50.2, 32.3, 19.7 and 13.5; PhTA: ${ }^{1} \mathrm{H}$ NMR (500 $\left.\mathrm{MHz}, \mathrm{CDCl}_{3}, 25^{\circ} \mathrm{C}\right) \delta(\mathrm{ppm}): 0.98\left(\mathrm{t}, 3 \mathrm{H}, \mathrm{CH}_{3}\right) 1.39\left(\mathrm{~m}, 2 \mathrm{H}, \mathrm{CH}_{3} \mathrm{CH}_{2}\right), 1.92(\mathrm{~m}, 2 \mathrm{H}$, $\left.\mathrm{CH}_{2} \mathrm{CH}_{2} \mathrm{~N}\right), 4.42\left(\mathrm{t}, 2 \mathrm{H}, \mathrm{CH}_{2} \mathrm{CH}_{2} \mathrm{~N}\right), 7.33$ (t, 1H, $\left.\mathrm{ArH}\right), 7.43$ (t, 2H, $\left.\mathrm{ArH}\right), 7.74$ (s, 1H, NCHC) and $7.84(\mathrm{~d}, 2 \mathrm{H}, \mathrm{ArH}) .{ }^{13} \mathrm{C} \mathrm{NMR}\left(500 \mathrm{MHz}, \mathrm{CDCl}_{3}, 25^{\circ} \mathrm{C}\right) \delta(\mathrm{ppm}): 147.9,131.0,129.1,128.4$, 125.9, 119.7, 50.3, 32.6, 20.1 and 13.9 (Figure S4). 

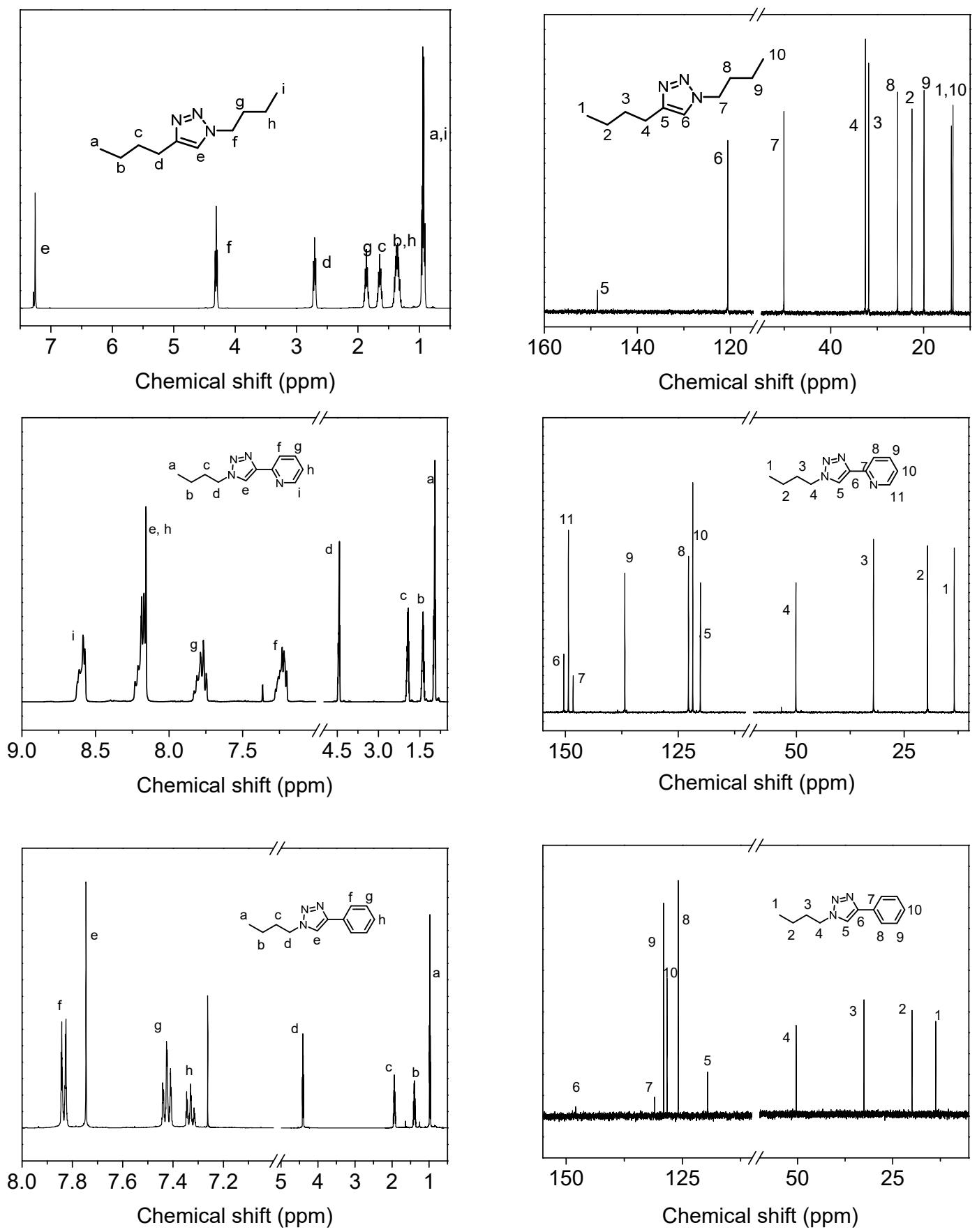

Figure S4. ${ }^{1} \mathrm{H}$ NMR and ${ }^{13} \mathrm{C}$ NMR spectra of BuTA (top), PyTA (middle) and PhTA (low) in $\mathrm{CDCl}_{3}$ at $25^{\circ} \mathrm{C}$. 
Synthesis of model ligand PEG $_{2 \mathbf{k}}$ TA. To a $10 \mathrm{~mL}$ Schlenk flask were added sequentially with 1-azidobutane (111.5 mg, $0.928 \mathrm{mmol})$, ay-PEG $2 \mathrm{k}(0.9280 \mathrm{~g}, 0.464 \mathrm{mmol})$, $\mathrm{CuI}(4.41 \mathrm{mg}, 0.0232 \mathrm{mmol})$ and $5 \mathrm{~mL}$ DCM. The reaction mixture was allowed to be stirred at room temperature overnight before addition of $5 \mathrm{~mL} \mathrm{DCM}$ for dilution. $\mathrm{Cu}$ catalyst was then removed by adding two equivalents of PMDETA followed by passing a neutral alumina column. The $\mathrm{PEG}_{2 \mathrm{k}} \mathrm{TA}$ was then purified by precipitating into large amount of diethyl ether three times and dried under vacuum to give $0.842 \mathrm{~g}$ white solid of the targeted $\mathrm{PEG}_{2 \mathrm{k}} \mathrm{TA}\left(86 \%\right.$ yield). ${ }^{1} \mathrm{H}$ $\operatorname{NMR}\left(500 \mathrm{MHz}, \mathrm{CDCl}_{3}, 25{ }^{\circ} \mathrm{C}\right) \delta(\mathrm{ppm}): 1.20(\mathrm{t}, 6 \mathrm{H}, \mathrm{CH}) 1.35\left(\mathrm{~m}, 2 \mathrm{H}, \mathrm{CH}_{3} \mathrm{CH}_{2} \mathrm{CH}_{2}\right), 1.93$ $\left(\mathrm{m}, 2 \mathrm{H}, \mathrm{CH}_{2} \mathrm{CH}_{2} \mathrm{~N}\right), 3.48-3.82\left(\mathrm{~m}, 182 \mathrm{H}, \mathrm{CH}_{2} \mathrm{CH}_{2} \mathrm{O}\right), 4.33\left(\mathrm{t}, 2 \mathrm{H}, \mathrm{CH}_{2} \mathrm{CH}_{2} \mathrm{~N}\right)$ and $8.09(\mathrm{~s}, 1 \mathrm{H}$, $\mathrm{NCHC}$.

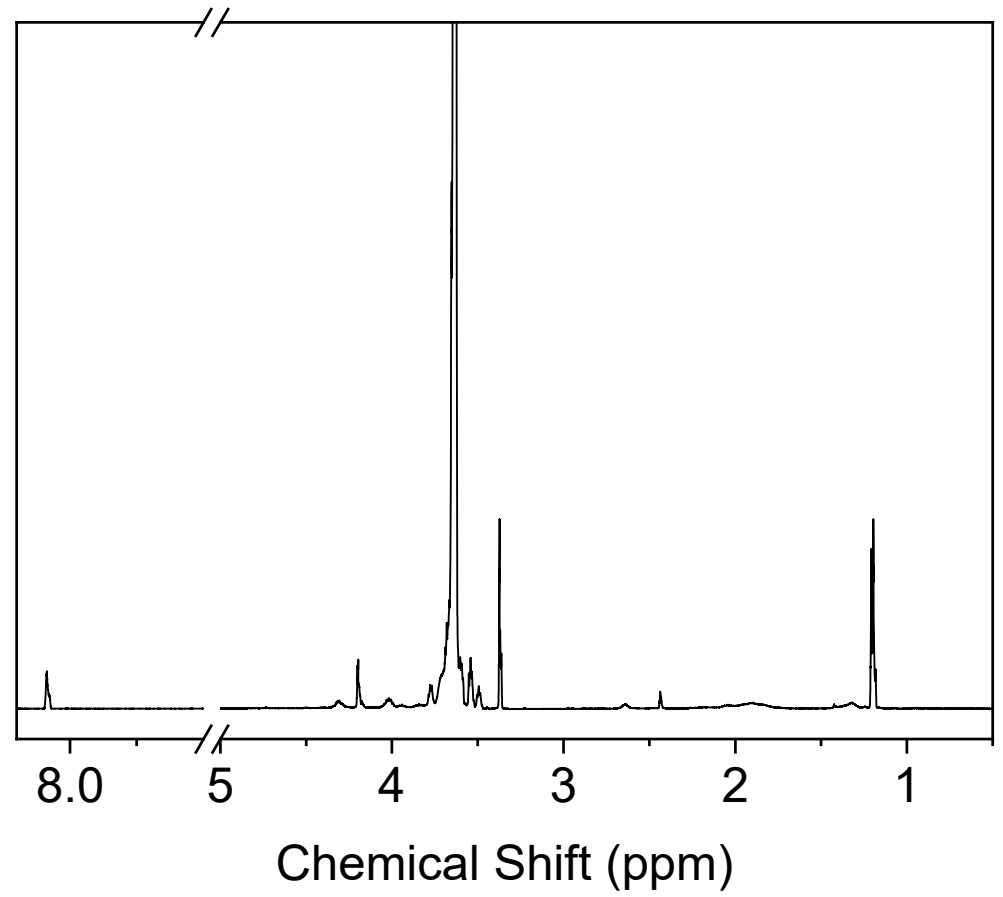

Figure S5. ${ }^{1} \mathrm{H}$ NMR spectrum of $\mathrm{PEG}_{2 \mathrm{k}} \mathrm{TA}$ in $\mathrm{CDCl}_{3}$ at $25{ }^{\circ} \mathrm{C}$. 
General procedure for Heck reaction. To a $3 \mathrm{~mL}$ vial containing model ligand catalyst or HBP catalyst $(0.1 \mu \mathrm{mol})$ were added sequentially with $\mathrm{K}_{3} \mathrm{PO}_{4}(0.3 \mathrm{mmol})$, iodobenzene $(0.1$ mmol), styrene $(0.2 \mathrm{mmol})$ and DMF $(0.5 \mathrm{~mL})$. The reaction mixture was stirred at $100{ }^{\circ} \mathrm{C}$. Samples were collected and diluted in $\mathrm{CDCl}_{3}$ for the assessment of substrate conversion by ${ }^{1} \mathrm{H}$ NMR spectroscopy.

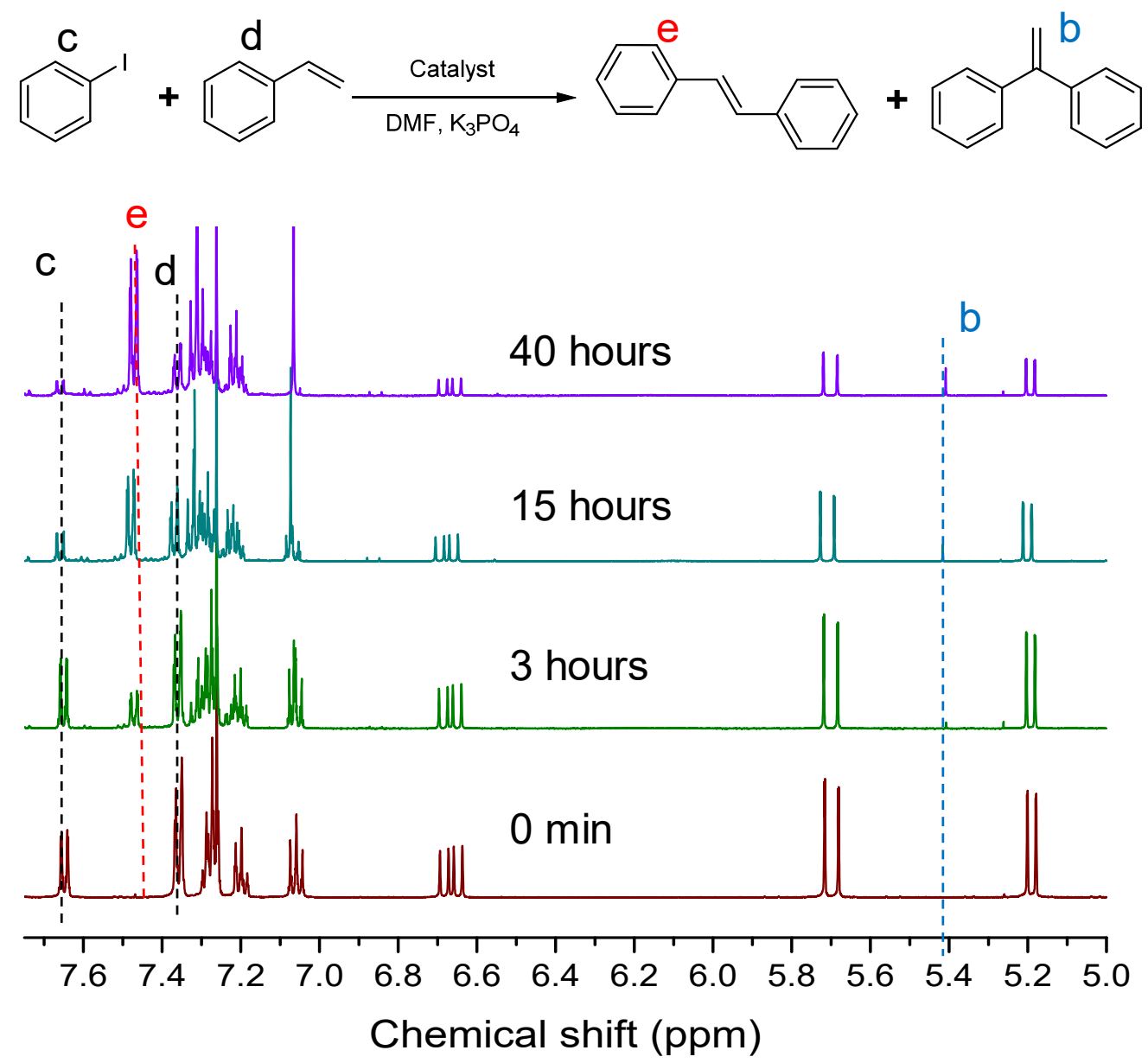

Figure S6. Stacked ${ }^{1} \mathrm{H}$ NMR spectra of Heck reaction catalyzed by $\mathrm{HBP}_{30}-\mathrm{Py}-\mathrm{Pd}$ as a function of time. 
Preparation of single crystal of Pd complex Pd(BuTA)2(OAc)2. A solution of ligand BuTA $(27.1 \mathrm{mg})$ in $0.5 \mathrm{~mL}$ DMF was added drop-wisely to $0.5 \mathrm{~mL}$ DMF solution of $\mathrm{Pd}(\mathrm{OAc})_{2}$ (11.2 mg) with constant stirring at room temperature. After stirring the mixture for 12 hours, 5 $\mathrm{mL}$ diethyl ether was added to the solution. The precipitated solid was filtered, washed by diethyl ether and air dried. The suitable single crystals for X-ray crystallography were grown from a two-phase solvent of n-hexane/DMF over a period of 3 days under $4{ }^{\circ} \mathrm{C}$.

Crystallographic studies. An arbitrary sphere of data was collected on a colorless tablet-like crystal, having approximate dimensions of $0.295 \times 0.222 \times 0.120 \mathrm{~mm}$, on a Bruker APEX-II diffractometer using a combination of $\omega$ - and $\varphi$-scans of $0.5^{\circ} .{ }^{5}$ Data were corrected for absorption and polarization effects and analyzed for space group determination. ${ }^{6}$ The structure was solved by dual-space methods and expanded routinely. ${ }^{7}$ The model was refined by full-matrix least-squares analysis of $\mathrm{F}^{2}$ against all reflections. ${ }^{8}$ All non-hydrogen atoms were refined with anisotropic atomic displacement parameters. Unless otherwise noted, hydrogen atoms were included in calculated positions. Atomic displacement parameters for the hydrogens were tied to the equivalent isotropic displacement parameter of the atom to which they are bonded $\left(U_{\text {iso }}(\mathrm{H})=1.5 U_{\text {eq }}(\mathrm{C})\right.$ for methyl, $1.2 U_{\text {eq }}(\mathrm{C})$ for all others $)$. There were two molecules of the complex in the unit cell of the primitive, centrosymmetric, monoclinic space group P21/c. 


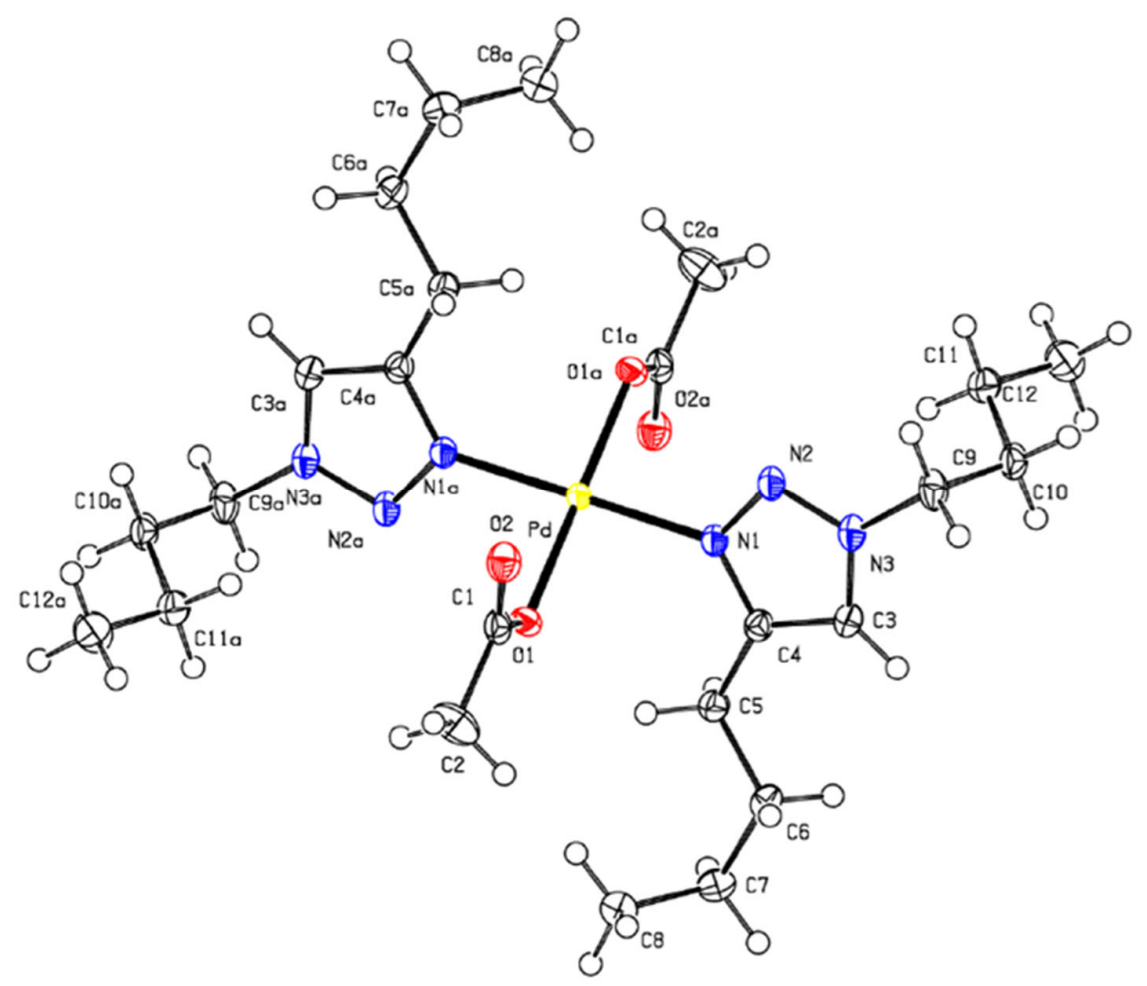

Figure S7. X-ray structure of $\mathrm{Pd}(\mathrm{BuTA})_{2}(\mathrm{OAc})_{2}$. 
Table S1. Crystal data and structure refinement for complex $\mathrm{Pd}(\mathrm{BuTA})_{2}(\mathrm{OAc})_{2}$.

\begin{tabular}{|c|c|c|c|c|}
\hline Empirical formula & \multicolumn{2}{|c|}{$\mathrm{C}_{24} \mathrm{H}_{44} \mathrm{~N}_{6} \mathrm{O}_{4} \mathrm{Pd}$} & Crystal size & $\begin{array}{c}0.295 \times 0.222 \times \\
0.120 \mathrm{~mm}^{3}\end{array}$ \\
\hline Formula weight & \multicolumn{2}{|c|}{587.05} & $\begin{array}{c}\theta \text { range for data } \\
\text { collection }\end{array}$ & 1.782 to $28.243^{\circ}$ \\
\hline Temperature & \multicolumn{2}{|c|}{$120(2) \mathrm{K}$} & Index ranges & $\begin{array}{c}-15 \leq \mathrm{h} \leq 15,-19 \leq \mathrm{k} \\
\leq 19,-11 \leq 1 \leq 11\end{array}$ \\
\hline Wavelength & \multicolumn{2}{|c|}{$0.71073 \AA$} & Reflections collected & 19565 \\
\hline Crystal system & \multicolumn{2}{|c|}{ Monoclinic } & $\begin{array}{l}\text { Independent } \\
\text { reflections }\end{array}$ & $3445\left[\mathrm{R}_{\mathrm{int}}=0.0280\right]$ \\
\hline Space group & \multicolumn{2}{|c|}{$\mathrm{P} 21 / \mathrm{c}$} & $\begin{array}{c}\text { Completeness to } \theta= \\
25.242^{\circ}\end{array}$ & $100.0 \%$ \\
\hline \multirow{3}{*}{ Unit cell dimensions } & $a=11.4716(11) \AA$ & $\alpha=90^{\circ}$ & Absorption correction & Numerical \\
\hline & $b=14.4072(14) \AA$ & $\begin{array}{c}\beta= \\
95.0631(13)^{\circ}\end{array}$ & $\begin{array}{l}\text { Max. and min. } \\
\text { transmission }\end{array}$ & 0.9656 and 0.8562 \\
\hline & $c=8.4898(8) \AA$ & $\gamma=90^{\circ}$ & Refinement method & $\begin{array}{c}\text { Full-matrix least- } \\
\text { squares on } \mathrm{F}^{2}\end{array}$ \\
\hline Volume & 1397.7 & & $\begin{array}{c}\text { Data / restraints / } \\
\text { parameters }\end{array}$ & $3445 / 0 / 163$ \\
\hline Z & 2 & & Goodness-of-fit on $\mathrm{F}^{2}$ & 1.039 \\
\hline Density (calculated) & 1.395 & & $\begin{array}{l}\text { Final } \mathrm{R} \text { indices } \\
\qquad[\mathrm{I}>2 \sigma(\mathrm{I})]\end{array}$ & $\begin{array}{c}\mathrm{R}_{1}=0.0224, \mathrm{wR}_{2}= \\
0.0510\end{array}$ \\
\hline $\begin{array}{c}\text { Absorption } \\
\text { coefficient }(\mu)\end{array}$ & 0.703 & & $\mathrm{R}$ indices (all data) & $\begin{array}{c}\mathrm{R}_{1}=0.0336, \mathrm{wR}_{2}= \\
0.0570\end{array}$ \\
\hline $\mathrm{F}(000)$ & 61 & & Extinction coefficient & $\mathrm{n} / \mathrm{a}$ \\
\hline Crystal color, habit & colorles & blet & $\begin{array}{l}\text { Largest diff. peak and } \\
\text { hole }\end{array}$ & $\begin{array}{c}0.431 \text { and }-0.579 \\
\mathrm{e}^{-} . \AA^{-3}\end{array}$ \\
\hline
\end{tabular}


Reaction of Pd complex with styrene. To a $1 \mathrm{~mL}$ vial containing $4.6 \mathrm{mg}$ complex $\mathrm{Pd}(\mathrm{BuTA})_{2}(\mathrm{OAc})_{2}, 25 \mu \mathrm{L}$ styrene was added. The reaction mixture was stirred at $100{ }^{\circ} \mathrm{C}$. A kinetics sample was taken by syringe after 4-hour reaction and diluted with $0.5 \mathrm{~mL} \mathrm{CDCl}_{3}$. The kinetics sample was characterized by ${ }^{1} \mathrm{H}$ NMR spectroscopy.

Reaction of $\mathrm{HBP}_{\mathbf{3 0 0}}$-Ph-Pd with styrene (the first and second cycles). To a $1 \mathrm{~mL}$ vial containing $9.9 \mathrm{mg} \mathrm{HBP}_{300}-\mathrm{Ph}-\mathrm{Pd}, 25 \mu \mathrm{L}$ styrene was added. The reaction mixture was stirred at $100{ }^{\circ} \mathrm{C}$. A kinetics sample was taken by syringe after 4-hour reaction, diluted with $0.5 \mathrm{~mL}$ $\mathrm{CDCl}_{3}$ and characterized by ${ }^{1} \mathrm{H}$ NMR spectroscopy. The reaction mixture was cooled to room temperature and evaporated under vacuum to remove solvent and unreacted styrene. The solid residue was then washed by $5 \mathrm{~mL}$ diethyl ether for three times before being dried under vacuum and applied for the second batch of redox reaction with $25 \mu \mathrm{L}$ styrene at $100{ }^{\circ} \mathrm{C}$.

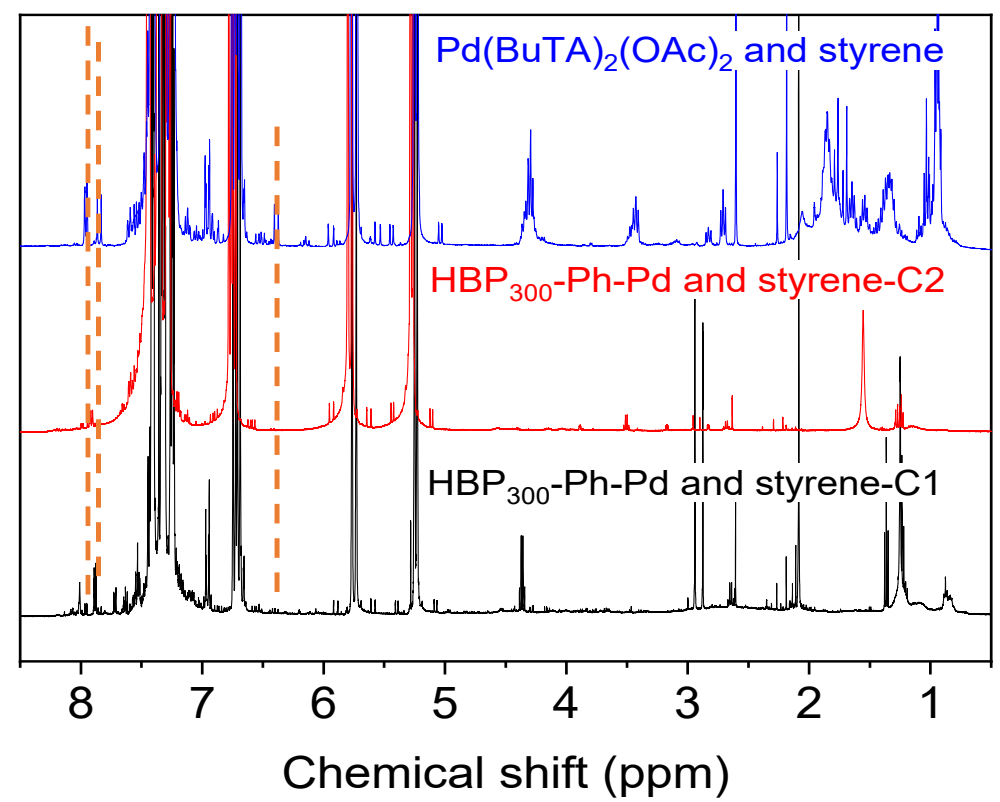

Figure S8. Stacked ${ }^{1} \mathrm{H}$ NMR spectra of styrene oxidized by $\mathrm{Pd}(\mathrm{BuTA})_{2}(\mathrm{OAc})_{2}, \mathrm{HBP}_{300} \mathrm{Ph}-\mathrm{Pd}$ for the first (C1) and second (C2) cycles. 
Procedure for recycling the catalysts. To a $3 \mathrm{~mL}$ vial containing model ligand catalyst or HBP catalyst $(0.1 \mu \mathrm{mol})$ were added sequentially with $\mathrm{K}_{3} \mathrm{PO}_{4}(0.3 \mathrm{mmol})$, iodobenzene $(0.1$ mmol), styrene $(0.2 \mathrm{mmol})$ and DMF $(0.5 \mathrm{~mL})$. The reaction mixture was stirred at $100{ }^{\circ} \mathrm{C}$. When reaction finished, the mixture was cooling to room temperature and evaporated under vacuum to remove solvent and the solid residue was washed by $5 \mathrm{~mL}$ diethyl ether for three times. The solid residue was dried thoroughly under vacuum and applied for next batch of Heck reaction where $0.1 \mathrm{mmol} \mathrm{K}_{3} \mathrm{PO}_{4}$, iodobenzene $(0.1 \mathrm{mmol})$, styrene $(0.2 \mathrm{mmol})$, and DMF $(0.5$ $\mathrm{mL}$ ) were successively added, and the mixture was stirred at $100^{\circ} \mathrm{C}$. The process was repeated 4 times within our investigation.

\section{References:}

1. Shi, Y.; Graff, R. W.; Cao, X. S.; Wang, X. F.; Gao, H. F., Chain-Growth Click Polymerization of $\mathrm{AB}(2)$ Monomers for the Formation of Hyperbranched Polymers with Low Polydispersities in a One-Pot Process. Angew. Chem., Int. Ed. 2015, 54, 7631-7635.

2. Cao, X. S.; Shi, Y.; Gan, W. P.; Naguib, H.; Wang, X. F.; Graff, R. W.; Gao, H. F., Effect of Monomer Structure on the CuAAC Polymerization To Produce Hyperbranched Polymers. Macromolecules 2016, 49, 5342-5349.

3. Gan, W. P.; Shi, Y.; Jing, B. X.; Cao, X. S.; Zhu, Y. X.; Gao, H. F., Produce Molecular Brushes with Ultrahigh Grafting Density Using Accelerated CuAAC Grafting-Onto Strategy. Macromolecules 2017, 50, 215-222.

4. $\quad$ http://www.ehs.ucsb.edu/files/docs/1s/factsheets/Azides_FS26.pdf. 
5. Ruf, M.; Lubben, J.; Hubschle, C. B., IDEAL - Invariom Derived Electron AnaLysis for APEX3. Acta Crystallogr. A. 2018, 74, A154-A154.

6. Krause, L.; Herbst-Irmer, R.; Sheldrick, G. M.; Stalke, D., Comparison of silver and molybdenum microfocus X-ray sources for single-crystal structure determination. J. Appl. Crystallogr. 2015, 48, 3-10.

7. Sheldrick, G. M., SHELXT - Integrated space-group and crystal-structure determination. Acta Crystallogr. A. 2015, 71, 3-8.

8. Sheldrick, G. M., Crystal structure refinement with SHELXL. Acta Crystallogr. C. 2015, $71,3-8$. 